\title{
EFEKTIFITAS TUTOR SEBAYA DALAM PEMBELAJARAN TRIGONOMETRI DI IKIP BUDI UTOMO MALANG
}

\author{
Welas Listiani ${ }^{1}$, Anik Kurniawati ${ }^{2}$, Ika Oktaviana Purnamasari ${ }^{3}$ \\ ${ }^{1,2,3}$ Program Studi Pendidikan Matematika, IKIP Budi Utomo Malang \\ welas.listiani1981@gmail.com
}

\begin{abstract}
Abstrak: Penelitian ini bertujuan untuk mendeskripsikan langkah-langkah pembelajaran Trigonometri dengan metode tutor sebaya yang dapat meningkatkan hasil belajar mahasiswa Program Studi Pendidikan Matematika. Penelitian ini mengambil subjek mahasiswa kelas 2016A di IKIP Budi Utomo Malang yang terdiri dari tiga puluh lima mahasiswa. Peneliti menggunakan pendekatan kualitatif dengan jenis penelitian tindakan kelas (PTK). Kegiatan penelitian ini dilaksanakan dalam tiga siklus, dengan persentase keberhasilan masing-masing siklus adalah 34\%, 50\% dan 70\%. Penelitian ini dilakukan dalam tiga siklus. Setiap siklus terdiri dari tahap perencanaan, pelaksanaan, observasi dan refleksi. Hasil penelitian menunjukkan bahwa langkah-langkah pembelajaran Trigonometri dengan metode tutor sebaya dapat meningkatkan hasil belajar mahasiswa Program Studi Pendidikan Matematika angkatan 2016A IKIP Budi Utomo Malang.
\end{abstract}

Kata Kunci: tutor sebaya, trigonometri; hasil belajar.

\section{Pendahuluan}

Trigonometri merupakan suatu cabang matematika yang mempelajari hubungan antara sudut segitiga dan sisisisinya. Selain itu, Trigonometri adalah salah satu mata kuliah yang harus ditempuh oleh mahasiswa Program Studi Pendidikan Matematika IKIP Budi Utomo Malang. Mata kuliah ini mendukung mata kuliah lain seperti Geometri, Kalkulus atau Analisis Vektor. Trigonometri juga memiliki banyak manfaat dalam kehidupan sehari-hari diantaranya dapat digunakan untuk mengukur sudut, panjang, keliling atau luas suatu bangun datar segitiga.

Namun, hasil wawancara peneliti dengan mahasiswa Program Studi Pendidikan Matematika angkatan 2016 A pada awal perkuliahan Trigonometri menunjukkan bahwa ada mahasiswa yang masih merasa asing dengan Trigonometri karena mereka berasal dari Sekolah Menengah Kejuruan (SMK).

Berdasarkan kondisi tersebut, maka perlu suatu nuansa pembelajaran yang dapat meningkatkan pemahaman atau kemampuan pemecahan masalah Trigonometri mahasiswa Program Studi Pendidikan Matematika IKIP Budi Utomo Malang. Salah satu cara yang dapat digunakan dalam pembelajaran Trigonometri adalah pembelajaran dengan metode tutor sebaya.

Tutor sebaya merupakan suatu metode yang dikembangkan oleh Vigotsky yang beraliran konstruktivis. Vigotsky menekankan pada perkembangan kecerdasan daripada pembelajaran prosedural dengan memanfaatkan anak-anak yang lebih cerdas untuk membantu teman mereka yang kurang cerdas. Hal ini dapat meningkatkan kemampuan pemecahan masalah pebelajar (mahasiswa) dari $\mathrm{x}$ menuju $\mathrm{x}+1$ karena adanya ZPD (Zone of Proximal Development) (Sutherland, 1992).

Berdasarkan paparan tersebut maka rumusan masalah dalam penelitian ini adalah bagaimana langkah-langkah pembelajaran Trigonometri dengan metode tutor sebaya dapat meningkatkan hasil belajar Trigonometri mahasiswa 


\section{Pi:Mathematics

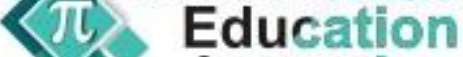 \\ Journal}

Program Studi Pendidikan Matematika angkatan 2016 A IKIP Budi Utomo Malang?

Selanjutnya, penelitian ini bertujuan untuk mendeskripsikan langkah-langkah pembelajaran Trigonometri dengan metode tutor sebaya dan untuk mengetahui peningkatan hasil belajar Trigonometri mahasiswa Program Studi Pendidikan Matematika angkatan 2016 A IKIP Budi Utomo Malang.

\section{Metode Penelitian}

Penelitian ini merupakan penelitian tindakan kelas (PTK) yang terdiri dari 3 siklus. Setiap siklus terdiri dari perencanaan, pelaksanaan tindakan, observasi, dan refleksi.

Tahap perencanaan terdiri dari menyiapkan Rencana Pelaksanaan Pembelajaran Semester (RPPS) dan instrument penelitian. Selanjutnya, tahap pelaksanaan dilakukan bersamaan dengan tahap observasi pembelajaran. Setelah itu, tahap refleksi dilakukan setelah pelaksanaan tes pada akhir pembelajaran untuk mengetahui tercapai atau tidaknya kriteria keberhasilan penelitian.

Kriteria keberhasilan dalam penelitian ini yaitu $70 \%$ mahasiswa sudah mencapai nilai minimal baik (B) atau skor minimal mahasiswa adalah 70 dan rata-rata hasil belajar Trigonometri mahasiswa Program Studi Pendidikan Matematika IKIP Budi Utomo Malang angkatan 2016 A lebih dari atau sama dengan 70 .

Instrumen penelitian dalam penelitian ini adalah lembar observasi pembelajaran, soal-soal tes dan wawancara. Subjek penelitian adalah mahasiswa Program Studi Pendidikan Matematika IKIP Budi Utomo Malang angkatan 2016 A sebanyak 35 mahasiswa.

Penelitian ini dilakukan di ruang C1.3 Kampus C IKIP Budi Utomo Malang mulai tanggal 5 Oktober 2016 sampai dengan 7 Desember 2016.

\section{Hasil dan Pembahasan Siklus I}

Tahap perencanaan dalam siklus I diawali dengan membuat RPPS tentang fungsi trigonometri dan grafik fungsi trigonometri. Dalam tahap pelaksanaan, dosen membagi mahasiswa menjadi 12 kelompok. Setiap kelompok terdiri dari 2 atau 3 mahasiswa. Salah satu anggota kelompok bertugas sebagai tutor pada kelompoknya dan dipilih oleh dosen. Selanjutnya, setiap kelompok mendapat lembar kerja untuk diselesaikan dan dipresentasikan hasilnya di kelas oleh tutor sebaya. Dosen yang menunjuk salah satu tutor untuk menyajikan hasil diskusi kelompoknya.

Observasi pada siklus I menunjukkan bahwa mahasiswa masih belum dapat bekerjasama dengan baik karena baru beradaptasi dengan temantemannya. Mahasiswa masih malu-malu atau takut dalam mengemukakan ide. Kondisi ini sesuai dengan pendapat Sumantri,M. dan Syaodih,N (2010) yang mengemukakan bahwa dalam tutor sebaya anak-anak belajar cara-cara mendekati orang asing, malu-malu atau berani, menjauhkan diri atau bersahabat.

Hasil tes pada siklus I menghasilkan rata-rata hasil belajar Trigonometri mahasiswa Program Studi Pendidikan Matematika angkatan 2016A sebesar 62 dan ada 34\% mahasiswa yang mendapat nilai baik (B). Hasil ini menunjukkan bahwa hasil belajar Trigonometri mahasiswa Program Studi Pendidikan Matematika angkatan 2016A IKIP Budi Utomo Utomo belum mencapai criteria keberhasilan.

Pada tahap refleksi diadakan wawancara dengan mahasiswa untuk mengetahui pendapat mahasiswa terhadap pembelajaran dengan tutor sebaya. Hasil wawanca menunjukkan bahwa mahasiswa menghendaki agar tutur dipilih sendiri oleh mahasiswa bukan oleh dosen agar mahasiswa lebih leluasa dalam menyampaikan ide-idenya. 
Berdasarkan hasil tersebut maka penelitian harus dilanjutkan ke siklus kedua dengan memperbaiki RPPS dan pembelajarannya.

\section{Siklus II}

Tahap perencanaan pada siklus II disiapkan instrument penelitian dan RPPS tentang trigonometri pada segitiga. RPPS tersebut kemudian dilaksanakan dengan cara yang serupa dengan siklus I namun ada perubahan dalam pemilihan tutor. Tutor dipilih sendiri oleh mahasiswa.

Hasil observasi pada siklus II menunjukkan bahwa mahasiswa sudah mulai bisa bekerjasama dengan baik, dapat lebih leluasa dalam berbagi dan menerima ide meskipun masih terlihat ragu-ragu dalam berpendapat. Mahasiwa masih perlu motivasi dari dosen untuk presentasi di kelas. Dosen masih harus menunjuk tutor untuk presentasi di kelas. Selain itu, hasil tes pada siklus II menunjukkan rata-rata hasil belajar Trigonometri sebesar 71 dan 50\% sudah mendapat nilai B.

Setelah diadakan refleksi, maka pembelajaran masih harus dilanjutkan pada siklus III karena belum memenuhi kriteria keberhasilan.

\section{Siklus III}

Penelitian dilanjutkan pada siklus III dengan menyiapkan instrument penelitian dan RPPS tentang kesamaan Trigonometri. Pembelajaran pada siklus III dilaksanakan sama dengan siklus II. Tetapi, dosen tidak menunjuk tutor yang harus presentasi melainkan memberi motivasi kepada mahasiswa agar dengan sukarela menyajikan hasil kerjanya kepada teman sekelas.

Hasil observasi pada siklus III menunjukkan bahwa mahasiswa sudah dapat berinteraksi dengan baik dengan teman sekelompoknya. Mahasiswa juga langsung menyajikan hasil kerjanya tanpa harus ditunjuk terlebih dahulu oleh dosen. Mahasiswa sudah dapat mengemukakan ide dengan percaya diri. Selanjutnya, tes pada siklus III menghasilkan rata-rata hasil belajar Trigoometri mahasiswa sebesar 74 dan $70 \%$ mahasiswa sudah memperoleh nilai $\mathrm{B}$.

Refleksi pada siklus III menunjukkan bahwa penelitian sudah dapat dihentikan karena kriteria keberhasilan penelitian sudah terpenuhi. Berikut ini ringkasan data hasil belajar siswa dari tiga siklus.

\section{Pembahasan}

Pada siklus I ditemukan bahwa mahasiswa masih belum bekerja secara maksimal dalam kelompoknya karena mereka baru bertemu dari berbagai daerah sehingga memerlukan waktu untuk beradaptasi. Kondisi ini sesuai dengan pendapat Sumantri,M. dan Syaodih,N (2010) yang mengemukakan bahwa dalam tutor sebaya anak-anak belajar cara-cara mendekati orang asing, malu-malu atau berani, menjauhkan diri atau bersahabat.

Pada siklus II, mahasiswa masih harus didorong oleh dosen untuk dapat mengemukakan ide-idenya. Hal ini sesuai dengan konsep Scaffolding yang dikemukakan Vigotsky dalam Mustaji dan Sugiarso (2005) yaitu pebelajar seharusnya diberi tugas-tugas kompleks, sulit, dan realistis dan kemudian diberikan bantuan secukupnya untuk menyelesaikan tugas-tugas.

Selanjutnya, pada siklus III, mahasiswa sudah dapat berdiskusi dengan baik yaitu aktif dalam mengemukakan pendapatnya karena prinsip-prinsip pembelajaran konstruktivis yang dikemukakan Suparno dalam Mustaji dan Sugiarso (2005) sudah terpenuhi dalam siklus III. Adapun prinsip-prinsip tersebut yaitu:
1. Pengetahuan dibangun oleh mahasiswa sendiri baik secara personal maupun sosial.

2. Pengetahuan tidak dapat dipindahkan dari pembelajar (dosen) kepada pebelajar (mahasiswa), kecuali dengan 
keaktifan mahasiswa itu sendiri untuk menalar.

3. Pebelajar aktif mengkonstruksi terus menerus, sehingga selalu terjadi perubahan konsep menuju konsep yang lebih rinci, lengkap, serta sesuai dengan konsep ilmiah.

4. Pembelajar sekedar membantu pebelajar dengan menyediakan sarana dan situasi agar proses konstruksi pebelajar berlangsung secara efektif dan efisien.

Selain itu, hasil belajar Trigonometri mahasiswa Program Studi Pendidikan Matematika Angakatan 2016 A IKIP Budi Utomo Malang tertulis dalam tabel berikut ini.

Tabel 1. Hasil Belajar Mahasiswa

\begin{tabular}{llc}
\hline Uraian & $\begin{array}{c}\text { Rata-rata } \\
\text { Hasil } \\
\text { Belajar }\end{array}$ & $\begin{array}{c}\text { Ketuntasan } \\
(\boldsymbol{\%})\end{array}$ \\
\hline Siklus I & 62 & 34 \\
Siklus II & 71 & 50 \\
Siklus III & 74 & 70 \\
\hline
\end{tabular}

Tabel tersebut menunjukkan adanya peningkatan hasil belajar Trigonometri dari siklus I ke siklus II dan ke siklus III melalui pembelajaran Trigonometri dengan metode tutor sebaya. Peningkatan ini sesuai dengan gagasan Vigotsky dalam Sutherland ( 1992) yaitu metode tutor sebaya dapat meningkatkan kemampuan pemecahan masalah pebelajar dari $\mathrm{x}$ menuju $\mathrm{x}+1$ karena adanya ZPD (Zone of Proximal Development).

Silver, H.F. dkk (2013) menegaskan bahwa model belajar berpasangan merupakan cara yang efektif dan efisien untuk meningkatkan keaktifan pembelajaran di kelas matematika apapun. Siswa dapat berpasangan dengan cepat dan bekerja bersama untuk menyelesaikan tugas singkat, atau tugas yang lebih teliti yang membutuhkan lebih banyak waktu atau perlu berpikir lebih rumit.

\section{Kesimpulan}

Penelitian ini menghasilkan simpulan sebagai berikut:

1. Langkah-langkah pembelajaran Trigonometri dengan metode tutor sebaya yaitu pada tahap pendahuluan, mahasiswa dibagi dalam kelompok-kelompok kecil dan mahasiswa memilih tutornya masingmasing. Pada tahap inti, mahasiswa diberi lembar kerja untuk didiskusikan dengan tutor kelompok. Kemudian tutor kelompok menyajikan hasil kerja kelompoknya di kelas untuk berbagi dengan kelompok lain. Pada tahap penutup, mahasiswa dan dosen menyimpulkan hasil diskusi kelas.

2. Rata-rata hasil belajar Trigonometri mahasiswa Program Studi Pendidikan Matematika angkatan 2016A IKIP Budi Utomo Malang meningkat dari siklus I ke siklus III sebesar $19 \%$ dan prosentase mahasiswa yang memperoleh nilai minimal B meningkat sebesar $36 \%$.

\section{Daftar Rujukan}

Arikunto,S dkk. 2007. Penelitian Tindakan Kelas. Jakarta: Bumi Aksara

Johnson, E,B. 2007. Contextual Teaching and Learning. Bandung: MLC.

Mok,K.K. dan Ho,Y.L. 1983. A Complete Course of General Mathematics. Hongkong: Hung Fung Book.

Muhsetyo, G. dkk. 2007. Pembelajaran Matematika SD. Jakarta: Universitas Terbuka.

Mustaji dan Sugiarso. 2005. Pembelajaran Berbasis Konstruktivistik. Surabaya: Unesa University Press.

Sharan,S. 2009. Handbook of Cooperative Learning. Yogyakarta: Imperium.

Silver,H.F., dkk. 2013. Pengajaran Matematika. Jakarta: Indeks. 
Sumantri,S. dan Syaodih,N. 2010. Perkembangan Peserta Didik. Jakarta: Universitas Terbuka.
Sutherland,P.

1992.

Cognitive Development Todays Piaget and His Critics. London: Paul Chapman 